\title{
Mineral composition of artisanal and commercial honeys from Venezuela: a comparison of sample pre-treatment strategies
}

\author{
Fátima Rodríguez-Ramos ${ }^{1,2}$ [D $\cdot$ Eunice Marcano ${ }^{2} \cdot$ Guillermina Aguiar $^{3} \cdot$ Jesús Ramos-Gamero $^{4}$
}

Received: 8 October 2020 / Accepted: 18 November 2020 / Published online: 25 November 2020

(c) Springer Nature Switzerland AG 2020

\begin{abstract}
The aim of this study was to evaluate the mineral composition of different artisanal and commercial honeys from 7 states in Venezuela, considering a simultaneous analysis of major and trace elements by Inductively Coupled Plasma Optical Spectroscopy (ICP-OES), and a comparison among sample pre-treatments including calcination, acid digestion, and dilution. Significant differences were found in the element concentrations between honeys depending on sample pretreatment. Acid digestion was the method selected for the analysis of all honey samples, which proved to be effective and reliable for a simultaneous multi-elemental determination using ICP-OES. The order of average concentration founded for elements in artisanal honeys was: $\mathrm{K}>\mathrm{P}>\mathrm{Mg}>\mathrm{Ca}>\mathrm{Na}>\mathrm{B}>\mathrm{Fe}>\mathrm{Mn}>\mathrm{Ba}>\mathrm{Zn}>\mathrm{Sr}$, while for commercial honeys was: $\mathrm{K}>\mathrm{Na}>\mathrm{Mg}>\mathrm{P}>\mathrm{Ca}>\mathrm{Fe}>\mathrm{B}>\mathrm{Mn}>\mathrm{Zn}>\mathrm{Sr}>\mathrm{Ba}$. Minerals as $\mathrm{As}, \mathrm{Cd}, \mathrm{Pb}$, and $\mathrm{Hg}$ were not detected in honey samples. The method showed good precision ( $<5 \%)$, accuracy (90-115\% recovery) and the limits of quantification and detection were acceptable for each element. By comparison of mineral composition between artisanal and commercial Venezuelan honeys, a not clear tendency was observed, reflecting that the mineral content is influenced by many environmental parameters, even by the preservation and processing strategies used for the treatment of commercial honeys. This research represents a good input due to the limited information related to mineral content in the Venezuelan honeys, considering the special characteristics as a tropical country, suitable for apiculture and with a great potential for growth the marketing of this product.
\end{abstract}

Keywords Venezuelan honey $\cdot$ ICP-OES · Dilution · Acid digestion · Calcination · Mineral composition

\section{Introduction}

Honey is defined by CODEX Alimentarius, as a natural sweet substance produced by honey bees from the nectar of plants or from secretions of plants living parts, which the bees collect, transform, deposit, dehydrate, store, and leave in the honey comb to ripen and mature [1]. The chemical composition of honeys depends on geographical origin, the biodiversity of flora, climate, and weather conditions, among other anthropogenic factors [2-4].
Mineral content in floral honey is low and mostly between 0.1 and $0.3 \%$ or 0.02 to $1.03 \mathrm{~g} / 100 \mathrm{~g}[5,6]$. Potassium is the main mineral, with an average of about one-third of the total, followed by calcium, magnesium, sodium, sulfur, and phosphorus; trace elements include iron, copper, zinc and manganese. The content of trace elements in honeys depends mainly on its botanical origin $[7,8]$. Honey is considered to be an important source of minerals required by humans, from both mineral contribution and its bioavailability $[9,10]$. Regarding heavy metals in honey, several

$\triangle$ Fátima Rodríguez-Ramos, frodriguez@userena.cl; Eunice Marcano, cjmarcano@yahoo.es; Guillermina Aguiar, cologia@gmail.com; Jesús Ramos-Gamero, jesus_g_ramos@hotmail.com | 'Departamento de Ingeniería de Alimentos, Universidad de La Serena, Raúl Bitrán Nachary 1305, La Serena, Chile. 'Laboratorio de Química Analítica, Centro Química, Instituto Venezolano de Investigaciones Científicas (IVIC), Altos de Pipe 1020A, Miranda, Venezuela. ${ }^{3}$ Centro de Ecología, Laboratorio de Ecofisiología Vegetal, (IVIC), Ve Altos de Pipe 1020A, Miranda, Venezuela. ${ }^{4}$ Centro de Biofísica, Laboratorio de Fisiología Molecular, (IVIC), Altos de Pipe 1020-A, Miranda, Venezuela. 
studies have been conducted to assess $\mathrm{As}, \mathrm{Cd}, \mathrm{Cr}, \mathrm{Hg}, \mathrm{Ni}$, and $\mathrm{Pb}$ in regions with industrial activities and industrial technological processes, where the pollution is a serious problem [4, 11]- [13]. The presence of a high concentration of metals in honeys may represent health risks and should be evaluated and quantified $[14,15]$. The metal content is a key indicator of the geographical origin of particular honey and in turn, can be used as a quality criterion [16]. The analysis of metals in honeys has been a complicated task due to the interferences derived from the matrix [9, $10,17]$. For this reason, the selection of the most suitable technique to pretreat the honey samples is relevant and necessary to destroy the organic matrix and extract the bound metal ions in the form of organic complexes $[9,18]$ with minimal losses of analyses of interest. Several elemental techniques have been used to study the mineral composition in honey. ICP-OES is a very attractive technique for the analysis of traces and essential elements, due to the fact that it presents good sensitivity, together with the advantage of simultaneously determining various elements in several spectral lines $[10,19,20]$. Other authors have also emphasized the benefits of ICP-OES, mainly due to its versatility and the reduction of maintenance and operation costs, in comparison with inductively-coupled plasma mass spectrometry (ICP-MS), recognizing its relevant sensitivity [7].

In Venezuela, contrasting in Europe, the consumption of honey is not restricted to a natural sweetener. The use is more oriented towards its medicinal application, due to its anti-flu effect and oropharyngeal when consumed mixed with lemon, milk, and spirits drinks, its healing action, laxative, sedative, antibiotic, antidiarrheal, to treat gastritis, ulcers, and eye conditions [21].The difference in Venezuelan honeys is closely related to its botanical origin, where the tropical environment presents a great diversity of apibotanical flora, influencing the organoleptic, sensory, and chemical composition of the honey of each region [22, 23]. However, being a tropical country, suitable for apiculture, Venezuela is not known abroad for the quality of its honey, but it exhibits a great potential for growth respect to the marketing of this product [24].

Several studies have been conducted to assess the chemical composition of Venezuelan honeys. Recently, Araujo et al. [24] showed the study of artisanal honeys from Zulia state (western region of Venezuela) to establish the sensory profile and physicochemical properties $(\mathrm{pH}$, free acidity, lactone acidity, total acidity, moisture content, diastase activity, color intensity, HMF and electrical conductivity). In a similar context, Ojeda de Rodríguez et al. [25] and Piccirillo et al. [26] evaluated also the quality of honey produced in Zulia State, including nitrogen and carbohydrate composition. Principal et al. [22] studied physicochemical and sensory characterization of Apis mellifera
L.'s honeys, but in this case from Lara and Yaracuy states. Vit et al. [27] studied honey samples from seven states of Venezuela to evaluate physicochemical parameters and antibacterial and antioxidant activities. Regarding the mineral content of Venezuelan honeys, Sulbarán De Ferrer et al. [28] evaluated levels of calcium, magnesium, copper, iron, manganese, phosphorus, and ash content of raw honey samples directly collected from different beekeepers in Zulia state, where potassium and phosphorous were found in major proportion, followed by sodium, calcium, magnesium, iron, manganese, and copper. The literature review indicates that previously published studies have not described an extensive mineral composition analysis of Venezuelan honeys from different locations.

The literature reviewed indicates that previously published studies have not described a more extensive mineral profile for Venezuelan honeys from various locations. For this reason, this study aimed to establish the mineral composition of different artisanal and commercial honeys from 7 states in Venezuela, by the use of a simultaneous analysis of major and trace elements by ICP-OES. Additionally, this study shows a comparison among different sample pretreatments for honey samples before the analysis, including calcination, acid digestion and dilution. This research represents a good input due to the restricted information regard to mineral profile of Venezuelan honeys.

\section{Materials and methods}

\subsection{Sample collection}

This study included twelve (12) Apis mellifera honey samples of multifloral types from seven different regions of central-western of Venezuela (See Fig. 1): six (6) of them were artisanal honeys: A1, B1, C1, D1, E1 and F1. The other six (6) samples were commercial honeys: A2, B2, C2, D2, E2, and $\mathrm{F} 2$. The artisanal honeys were directly obtained from apiarists and commercial honeys were purchased in local markets in each region; The honey samples were provided in a sterile appropriate glass container and refrigerated at $4{ }^{\circ} \mathrm{C}$ for further analysis.

\subsection{Equipment}

A Perkin Elmer Optima 3000 XL radial Inductively Coupled Plasma Optical Emission Spectrometer (ICP-OES, Norwalk, $\mathrm{CT}$, USA) was used, with the following working conditions: $1.3 \mathrm{~kW}$ of radio frequency power generator, $0.5 \mathrm{~L} / \mathrm{min}$ nebulizer flow rate, $15 \mathrm{~L} / \mathrm{min}$ plasma gas flow rate, $5 \mathrm{~mm}$ of observation height above load coil and $1.5 \mathrm{ml} / \mathrm{min}$ of sample aspiration rate. The wavelength for the analysis of each analyte was selected according to their sensitivity and 
Fig. 1 Geographical locations of honey samples studied on the map of Venezuela

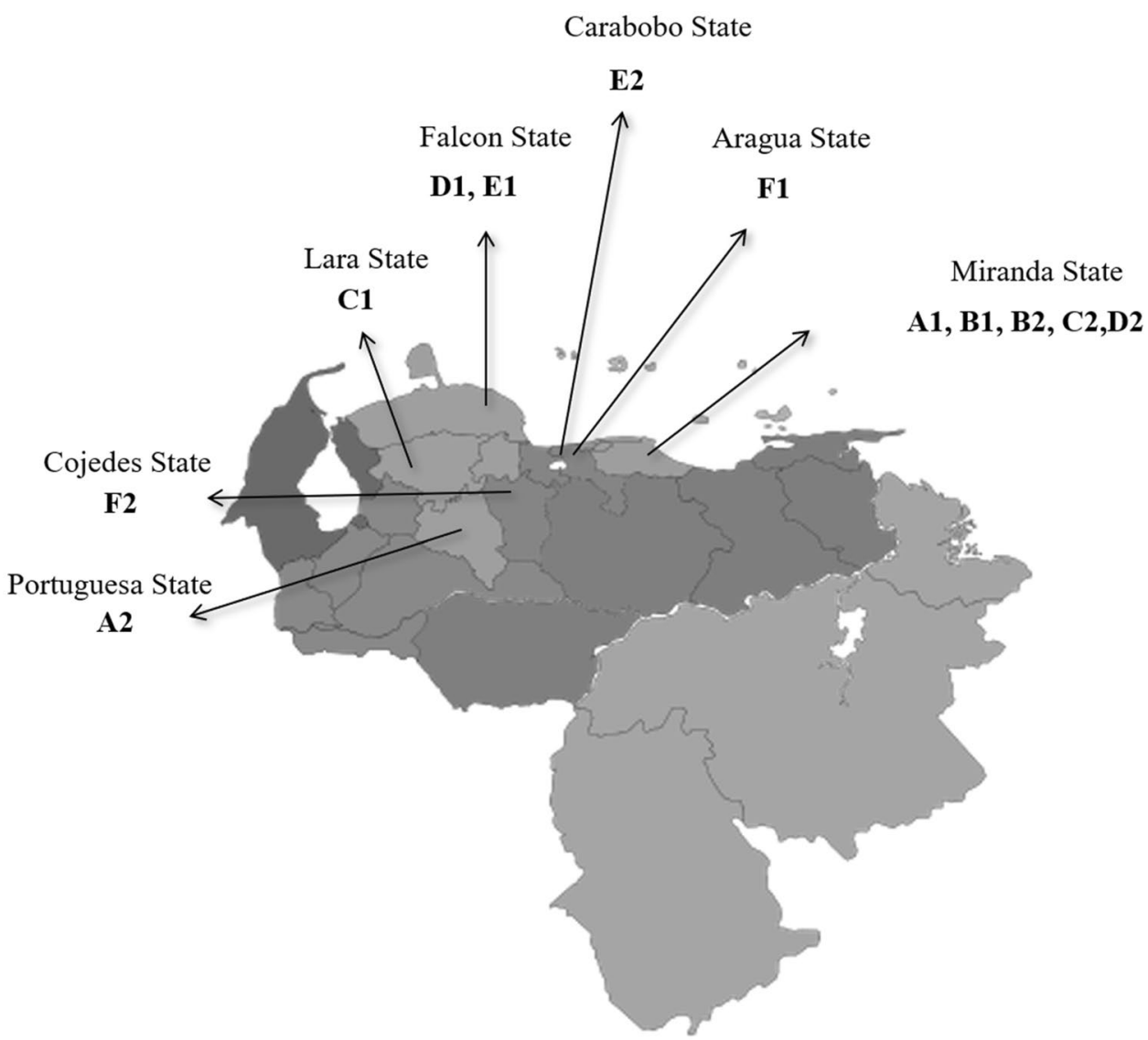

absence of spectral interferences, and the plasma parameters according to the average sensibility for elements. The wavelengths ( $\mathrm{nm}$ ), used were: Boron (B): $249.772 \mathrm{~nm}$, Barium (Ba): 233.527 nm; Calcium (Ca): 317.933 nm; Iron (Fe): $259.939 \mathrm{~nm}$; Potassium (K): $766.490 \mathrm{~nm}$; Magnesium (Mg): $280.271 \mathrm{~nm}$; Manganese (Mn): $260.568 \mathrm{~nm}$; Sodium (Na): 589.592 nm; Phosphorus (P): 214.914 nm; Strontium (Sr): 407.771 nm; Zinc (Zn): 202.548 nm; Arsenic (As): $188.979 \mathrm{~nm}$; Lead (Pb):220.353 nm, Cadmium (Cd):228.802 nm, and Mercury (Hg): $194.168 \mathrm{~nm}$.

\subsection{Reagents and standard solutions}

All the reagents used were analytical grade. High purity deionized water $\left(18.2 \mathrm{M} \Omega \mathrm{cm}^{-1}\right.$ ) from a MilliQ Element water purification system (Millipore, Bedford, MA, USA) was used. Standard solutions were prepared for major elements (Ca, K, Mg, Na and P) from 1000 mg/L stock solutions (MERCK, Darmstadt, Germany) and K (Fisher Scientific Company, NJ, USA). For the standards of the trace elements, a stock of ICP multielement Solution IV was used (MERCK, Darmstadt, Germany). The samples were treated with suprapure $\mathrm{HNO}_{3}$ (p.a, 65\%, MERCK, Darmstad, Germany) and $\mathrm{H}_{2} \mathrm{O}_{2}$ (p.a, 37\%, Riedel-de Häen, Germany).
For the operation of the ICP-OES spectrometer ultrahigh purity argon gas was used.

\subsection{Analytical procedures for the honeys pre-treatments}

To perform the quantitative analysis of minerals in honey samples by ICP-OES, three different strategies to pretreat all honey samples were tested: dilution, acid digestion and calcination. The strategies are detailed below.

Dilution: pretreatment of honey samples by dilution was according to methodology reported by Mendes et al. [29] with modifications. Triplicates of $2.5 \mathrm{~g}$ of each honey sample were weight and dissolved in a solution of $\mathrm{HNO}_{3}$ $1 \%$ using ultrasonication for $10 \mathrm{~min}$. Then, the solution was filtered and the volume was completed to a final volume of $50 \mathrm{~mL}$ in a volumetric flask. A blank was also prepared in the same way.

Acid Digestion: the methodology used was according to Farooque and Ahmed. [30], with modifications. Triplicates of $5.0 \mathrm{~g}$ of each honey sample were weight in digestion beakers, and then it was added $10 \mathrm{~mL}$ of $\mathrm{HNO}_{3} 65 \%$ (p.a, $65 \%$, MERCK, Darmstad, Germany). The resulting mixture reacted for $12 \mathrm{~h}$. After, a heating up at $60^{\circ} \mathrm{C}$ was performed for $2 \mathrm{~h}$, and $10 \mathrm{~mL}$ of $\mathrm{H}_{2} \mathrm{O}_{2} 37 \%$ v/v (p.a, 37\%, Riedel-de 
Häen, Germany) were added to the residue. In order to guarantee the complete reaction, the heating continued at $60^{\circ} \mathrm{C}$ for $2 \mathrm{~h}$. Finally, the resulting solution was dissolved with deionized water and completed a final volume of $50 \mathrm{~mL}$ with deionized water. A blank was also prepared in the same way.

Calcination: The analytical procedure followed for calcination was the method suggested in the Venezuelan regulations for honey quality COVENIN 2136-84 [31], Triplicates of $10.0 \mathrm{~g}$ of honey samples were weighed in crucibles and placed in a muffle. The temperature of the muffle was gradually increased, starting at $60^{\circ} \mathrm{C}$ for $12 \mathrm{~h}$, then, $105^{\circ} \mathrm{C}$ and $350^{\circ} \mathrm{C}$ for $2 \mathrm{~h}$ respectively, and finally increased up to $550^{\circ} \mathrm{C}$ for $5 \mathrm{~h}$. The ash residue was dissolved in $5 \mathrm{ml}$ de $\mathrm{HNO}_{3} 65 \% \mathrm{v} / \mathrm{v}$, and heated at $60^{\circ} \mathrm{C}$ for $30 \mathrm{~min}$. Finally, the solution was transferred to a $50 \mathrm{~mL}$-flask and complete with deionized water. The blank treatment for these samples was made adding $5 \mathrm{~mL}$ of $\mathrm{HNO}_{3} 65 \% \mathrm{v} / \mathrm{v}$ in a flask and filling it up to $50 \mathrm{~mL}$ with deionized water.

\subsection{Recovery test, detection and quantification limits}

The accuracy of the selected analytical strategy for pretreatment of samples was evaluated by a spike recovery analysis at two (2) known concentrations ( 5 and $10 \mathrm{mg} . \mathrm{L}^{-1}$ ) of $\mathrm{B}, \mathrm{Ba}, \mathrm{Ca}, \mathrm{Fe}, \mathrm{K}, \mathrm{Mg}, \mathrm{Mn}, \mathrm{Na}, \mathrm{Sr}$, and $\mathrm{Zn}$. Precision is defined by IUPAC as the closeness of agreement between independent test results obtained under stipulated conditions, and it is usually specified in terms of standard deviation or relative standard deviation. In this work, the precision was evaluated by the use of relative standard deviation. In order to determinate the detection (LOD) and quantification (LOQ) limits for each element, guidelines from ICH were considered [32], using the following equations: $\mathrm{LOD}=3.3 \mathrm{SD} / \mathrm{b}$; $L O Q=10 \mathrm{SD} / \mathrm{b}$, where: $S D$ is the standard deviation of the response and $b$, is the slope of the calibration curve. Ten (10) replicates of a digestion blank were considered to estimate LOD and LOQ.

\subsection{Statistical analysis}

The effect of each pretreatment strategy for honey samples on mineral content was performed with the Analysis of Variance (ANOVA) to evaluate significant differences $(p<0.05)$ between means considering a confidence level of $95 \%$, followed by the Multiple Range Test to demonstrate the existence of homogeneous groups. Additionally, also one-way ANOVA was used to evaluate significant differences $(p<0.05)$ between means for mineral content for artisanal and commercial honeys among regions. The software used was Statgraphics Centurion XVI (Statistical Graphics Co., Rockville, MD, USA).

\section{Results and discussion}

\subsection{Selection of honey pretreatment strategy}

The mineral analysis performed in this work included the study of major minerals in honey matrices such as $\mathrm{Na}$, $\mathrm{Ca}, \mathrm{K}, \mathrm{Mg}$, and $\mathrm{P}$; microelements: $\mathrm{B}, \mathrm{Ba}, \mathrm{Fe}, \mathrm{Mn}, \mathrm{Sr}$, and $\mathrm{Zn}$; and toxic elements as $\mathrm{Pb}, \mathrm{As}, \mathrm{Cd}$, and $\mathrm{Hg}$. The concentration of these 15 elements was measured in twelve different types of honeys (six artisanal and six commercial) collected in 7 different geographical regions of Venezuela. First, the selection of the strategy for the pretreatment of honeys was evaluated among dilution, acid digestion and calcination. The results for this evaluation are shown in Table 1. $\mathrm{K}$ was the element found in major proportion in all the pretreatment strategies evaluated, however a significant difference $(p<0.05)$ was observed between acid digestion and calcination. After $\mathrm{K}, \mathrm{Ca}$, and $P$ were the elements found in high proportion, with no significant differences $(p>0.05)$ among pretreatments for calcium, but for phosphorous a significant difference $(p<0.05)$ was observed for acid digestion in comparison with calcination and dilution.

Differences can be attributed to the volatilization losses due to the high temperatures which the honeys were subjected, where these elements could be linked to organometallic compounds, in which make them more thermolabile. On the other hand, the concentration of $\mathrm{Ba}, \mathrm{Ca}, \mathrm{Fe}, \mathrm{Mg}, \mathrm{Mn}, \mathrm{P}, \mathrm{Sr}$, and $\mathrm{Zn}$ was independent of strategy treatment, reflected in their significance, the calcination method showed in general poor precision. This behavior was similar to reported by Tuzen et al. [33] who evaluated the efficiency of calcination with a muffle furnace as compared to other ash-generating techniques to study heavy metals in honey samples, concluded that calcination via a muffle furnace resulted in the least precise and most disperse results.

Solid phase extraction by the use of mineral acids can be advantageous because it destroys all of the organic matter present in the matrix of honey, thereby reducing analysis time and risks of analyte loss that could affect result reliability, while in calcination procedures, the prevention of losses in the interior of the muffle furnace can be a complex process to regulate, directly affecting the distribution of the data obtained and the variability in the response. Then, these variations constitute another challenge during calcination via a muffle furnace [12]. The determination of inorganic components of honey by Inductively Coupled Plasma Optical Emission Spectrometry (ICP-OES) is useful considering the multielement characteristics that permit a rapid analysis, with good precision and accuracy, but, honey is a complex 
Table 1 Trace and major elements content in honey samples for pretreatment strategies evaluated

\begin{tabular}{|c|c|c|c|c|c|c|c|c|c|}
\hline \multirow{2}{*}{ Element } & \multicolumn{3}{|c|}{ Acid digestion } & \multicolumn{3}{|l|}{ Calcination } & \multicolumn{3}{|l|}{ Dilution } \\
\hline & $X(\mathrm{mg} / \mathrm{kg})$ & SD & RSD (\%) & $X(\mathrm{mg} / \mathrm{kg})$ & SD & RSD (\%) & $\mathrm{X}(\mathrm{mg} / \mathrm{kg})$ & SD & RSD (\%) \\
\hline B & $6.4^{b}$ & 0.1 & 1.3 & $4.3^{\mathrm{a}}$ & 0.3 & 6.1 & $7.1^{c}$ & 0.2 & 2.0 \\
\hline $\mathrm{Ba}$ & $0.1^{\mathrm{a}}$ & 0.0 & 4.7 & $0.1^{\mathrm{a}}$ & 0.1 & 7.9 & $0.1^{\mathrm{a}}$ & 0.0 & 8.3 \\
\hline $\mathrm{Ca}$ & $54.6^{a}$ & 5.1 & 9.3 & $58.4^{\mathrm{a}}$ & 5.4 & 9.2 & $53.9^{a}$ & 0.2 & 0.44 \\
\hline $\mathrm{Fe}$ & $2.6^{\mathrm{a}}$ & 0.0 & 0.9 & $3.2^{\mathrm{b}}$ & 0.3 & 9.2 & $2.6^{\mathrm{a}}$ & 0.0 & 1.03 \\
\hline K & $333.5^{\mathrm{b}}$ & 4.2 & 1.3 & $231.8^{\mathrm{a}}$ & 80.6 & 34.8 & $309.5^{\mathrm{ab}}$ & 1.7 & 0.5 \\
\hline$M g$ & $5.2^{\mathrm{a}}$ & 0.2 & 4.4 & $4.8^{\mathrm{a}}$ & 0.4 & 7.6 & $4.9^{\mathrm{a}}$ & 0.1 & 1.2 \\
\hline$M n$ & $0.5^{b}$ & 0.0 & 4.1 & $0.6^{c}$ & 0.0 & 7.3 & $0.3^{\mathrm{a}}$ & 0.0 & 2.6 \\
\hline $\mathrm{Na}$ & $11.2^{\mathrm{a}}$ & 0.00 & 0.0 & $23.8^{\mathrm{b}}$ & 8.8 & 36.9 & $25.6^{\mathrm{b}}$ & 0.5 & 2.1 \\
\hline$P$ & $28.2^{\mathrm{a}}$ & 0.1 & 0.5 & $37.6^{\mathrm{b}}$ & 1.6 & 4.3 & $38.8^{\mathrm{b}}$ & 0.7 & 1.8 \\
\hline Sr & $0.2^{\mathrm{ab}}$ & 0.0 & 5.5 & $0.2^{\mathrm{a}}$ & 0.0 & 7.7 & $0.2^{\mathrm{b}}$ & 0.0 & 0.5 \\
\hline $\mathrm{Zn}$ & $9.8^{\mathrm{a}}$ & 0.5 & 5.1 & $9.7^{\mathrm{a}}$ & 1.0 & 10.5 & $10.5^{\mathrm{a}}$ & 0.1 & 1.3 \\
\hline
\end{tabular}

$X$ Average, $S$ standard deviation, $R S D$ relative standard deviation, ND under detection limit. Values represent the mean $\pm S D$ of three replicates $(n=3)$. Different lowercase letters in same row indicate that values are significantly different $(p<0.05)$ matrix highly rich in organic matter and different strategies for sample treatment have been proposed [29]. In this context, the best condition of analysis for a particular mineral species is not necessarily equal for all.

The results for dilution strategy were similar to those obtained by the acid digestion, however, it is important to consider that honey is highly rich in sugar and its content in organic complexes is elevated, bringing with it a large number of interferences derived from the matrix, making necessary a proper treatment of the sample with mineral acids to destroy this organic content and be able to extract metal ions bound in organic complexes [29, 34, 35]. It would be very difficult to achieve using a simple dilution. The effects of the matrix have been recognized as an important source of interference in the analysis carried in ICP-OES, especially when the sugar amount found in each sample may vary depending on the type and origin of honey. The acid digestion strategy could give a more homogeneous treatment of the sample, considering the variation that may exist in chemical composition. For previous reasons, the strategy selected to perform the analysis was acid digestion for all the honey samples. In general, the elements $\mathrm{Mg}, \mathrm{Zn}, \mathrm{Ca}$, and Ba showed no significant differences among pretreatments. The strategy that showed the greatest variability among the means was calcination, with high percentages of relative standard deviation, reflected especially for $\mathrm{K}(34.8 \%)$ and $\mathrm{Na}(36.9 \%)$ and in a minor proportion of error for $\mathrm{Ca}$, Fe and $\mathrm{Zn}$. While acid digestion (RSD 0.03-9.3\%) and dilution (RSD 0.44-8.4\%) strategies showed a low range for variability among the means. $\mathrm{Pb}, \mathrm{As}, \mathrm{Hg}$ and $\mathrm{Cd}$ were considered in this assay for strategy selection, but were not detected in the sample selected for this purpose.

\subsection{Analysis of mineral composition in artisanal and commercial honeys by ICP-OES}

After the selection of pretreatment strategy was performed, the mineral analysis by ICP-OES using acid digestion for artisanal and commercial Venezuelan honeys was developed, considering twelve (12) honey samples from different states of Venezuela: Miranda, Lara, Falcon, Aragua, Cojedes, Portuguesa and Carabobo. The results for mineral analysis in artisanal and commercial honeys are shown in Table 2 and Table 3, respectively.

In artisanal and commercial honeys, the major elements quantified, were: $\mathrm{K}, \mathrm{P}, \mathrm{Na}, \mathrm{Mg}$ and $\mathrm{Ca}$. For all artisanal honeys studied, $K$ was the element found in greater proportion followed by $\mathrm{P}$ with a concentration range of $648-4895 \mathrm{mg} / \mathrm{kg}$ and $63.6-434 \mathrm{mg} / \mathrm{kg}$, respectively. These results for $\mathrm{P}$ were found according to Bogdanov and Pohl. $[8,10]$ After these elements, Ca $(26.5-69 \mathrm{mg} / \mathrm{kg})$ was the most abundant in honeys from Miranda and Falcon states, with a range highly close to results reported by Karabagias et al. [19] (37.30-68.36 mg/kg) for citrus, fir, multifloral, pine and thyme honeys from Greece, Cyprus, Egypt, Spain, and Morocco. Na followed Ca in concentration for Miranda, Lara y Aragua states. Levels of $\mathrm{K}$ showed not significant differences $(p>0.05)$ among A1, C1, D1, E1 and $\mathrm{F} 1$, but for the remaining elements, there were significant differences among each state studied. $\mathrm{Ba}, \mathrm{Fe}, \mathrm{Sr}$ and $\mathrm{Zn}$ were the elements found in minor proportion for all honey samples. Honeys from similar states (A1, B1 from Miranda and D1, E1 from Falcón) presented significant differences $(p<0.05)$ among all minerals studied, even though the regions share similarities in agroclimatic conditions and characteristics. $\mathrm{Pb}, \mathrm{As}, \mathrm{Hg}$ and $\mathrm{Cd}$ were studied in artisanal honeys, but were no detected because the levels were 
Table 2 Concentrations $(\mathrm{mg} / \mathrm{kg})$ of elements detected in artisanal honeys

\begin{tabular}{|c|c|c|c|c|c|c|}
\hline Element & $\begin{array}{l}\text { A1 } \\
\text { (Miranda) }\end{array}$ & $\begin{array}{l}\text { B1 } \\
\text { (Miranda) }\end{array}$ & $\begin{array}{l}\text { C1 } \\
\text { (Lara) }\end{array}$ & $\begin{array}{l}\text { D1 } \\
\text { (Falcón) }\end{array}$ & $\begin{array}{l}\text { E1 } \\
\text { (Falcón) }\end{array}$ & $\begin{array}{l}\text { F1 } \\
\text { (Aragua) }\end{array}$ \\
\hline B & $3.31 \pm 0.01^{\mathrm{a}}$ & $3.37 \pm 0.01^{b}$ & $3.91 \pm 0.02^{f}$ & $3.85 \pm 0.01^{\mathrm{e}}$ & $3.80 \pm 0.01^{d}$ & $3.54 \pm 0.02^{c}$ \\
\hline $\mathrm{Ba}$ & $0.34 \pm 0.02^{b}$ & $0.24 \pm 0.01^{\mathrm{a}}$ & $0.63 \pm 0.03^{c}$ & $1.71 \pm 0.08^{d}$ & $0.37 \pm 0.02^{b}$ & $0.59 \pm 0.01^{c}$ \\
\hline $\mathrm{Ca}$ & $26.50 \pm 0.50^{\mathrm{a}}$ & $69.00 \pm 1.00^{f}$ & $41.4 \pm 0.8^{d}$ & $32.30 \pm 0.50^{c}$ & $45.6 \pm 0.02^{\mathrm{e}}$ & $30.2 \pm 0.01^{b}$ \\
\hline $\mathrm{Fe}$ & $0.63 \pm 0.01^{\mathrm{a}}$ & $3.96 \pm 0.03^{f}$ & $0.81 \pm 0.01^{\mathrm{b}}$ & $0.99 \pm 0.01^{c}$ & $1.66 \pm 0.01^{d}$ & $2.02 \pm 0.01^{\mathrm{e}}$ \\
\hline K & $666.00 \pm 15.00^{\mathrm{a}}$ & $4895 \pm 110^{b}$ & $648.00 \pm 14.00^{\mathrm{a}}$ & $690.00 \pm 15.00^{a}$ & $708 \pm 15^{\mathrm{a}}$ & $656.00 \pm 10.00^{a}$ \\
\hline $\mathrm{Mg}$ & $5.02 \pm 0.05^{\mathrm{a}}$ & $150.00 \pm 5.00^{c}$ & $6.99 \pm 0.03^{a b}$ & $8.22 \pm 0.06^{a b}$ & $9.5 \pm 0.1^{b}$ & $7.50 \pm 0.03 \mathrm{ab}$ \\
\hline $\mathrm{Mn}$ & $0.29 \pm 0.01^{\mathrm{a}}$ & $0.65 \pm 0.04^{e}$ & $2.56 \pm 0.01^{f}$ & $0.39 \pm 0.01^{c}$ & $0.49 \pm 0.01^{d}$ & $0.35 \pm 0.01^{b}$ \\
\hline $\mathrm{Na}$ & $43.40 \pm 0.80^{d}$ & $45.40 \pm 0.50^{\mathrm{e}}$ & $49.2 \pm 0.40^{f}$ & $20.20 \pm 0.40^{\mathrm{a}}$ & $33.40 \pm 0.60^{b}$ & $39.60 \pm 0.70^{c}$ \\
\hline $\mathrm{P}$ & $94.00 \pm 2.00^{c}$ & $434.00 \pm 10.00^{f}$ & $65.80 \pm 1.50^{\mathrm{a}}$ & $63.60 \pm 1.40^{\mathrm{a}}$ & $133.00 \pm 3.00^{\mathrm{e}}$ & $84.00 \pm 2.00^{b}$ \\
\hline $\mathrm{Sr}$ & $0.091 \pm 0.001^{\mathrm{a}}$ & $0.15 \pm 0.01^{b}$ & $0.27 \pm 0.01^{d}$ & $0.32 \pm 0.01^{f}$ & $0.18 \pm 0.01^{c}$ & $0.30 \pm 0.01^{\mathrm{e}}$ \\
\hline $\mathrm{Zn}$ & $0.67 \pm 0.04^{\mathrm{a}}$ & $0.77 \pm 0.04^{c}$ & $0.75 \pm 0.04^{b c}$ & $0.84 \pm 0.05^{d}$ & $0.69 \pm 0.04^{\mathrm{ab}}$ & $0.79 \pm 0.03^{c d}$ \\
\hline
\end{tabular}

Values represent the mean \pm SD of three replicates $(n=3)$. Different lowercase letters in same row indicate that values are significantly different $(p<0.05)$

Table 3 Concentrations (mg/ $\mathrm{kg}$ ) of element detected in commercial honeys

\begin{tabular}{lllllll}
\hline Element & $\begin{array}{l}\text { A2 } \\
\text { (Portuguesa) }\end{array}$ & $\begin{array}{l}\text { B2 } \\
\text { (Miranda) }\end{array}$ & $\begin{array}{l}\text { C2 } \\
\text { (Miranda) }\end{array}$ & $\begin{array}{l}\text { D2 } \\
\text { (Miranda) }\end{array}$ & $\begin{array}{l}\text { E2 } \\
\text { (Carabobo) }\end{array}$ & $\begin{array}{l}\text { F2 } \\
\text { (Cojedes) }\end{array}$ \\
\hline $\mathrm{B}$ & $4.95 \pm 0.03^{\mathrm{f}}$ & $0.44 \pm 0.00^{\mathrm{a}}$ & $2.21 \pm 0.01^{\mathrm{b}}$ & $2.55 \pm 0.02^{\mathrm{c}}$ & $3.19 \pm 0.02^{\mathrm{d}}$ & $4.79 \pm 0.05^{\mathrm{e}}$ \\
$\mathrm{Ba}$ & $0.58 \pm 0.03^{\mathrm{c}}$ & $0.28 \pm 0.01^{\mathrm{a}}$ & $0.27 \pm 0.02^{\mathrm{a}}$ & $0.41 \pm 0.03^{\mathrm{b}}$ & $0.39 \pm 0.02^{\mathrm{b}}$ & $0.51 \pm 0.03^{\mathrm{c}}$ \\
$\mathrm{Ca}$ & $71.9 \pm 0.4^{\mathrm{f}}$ & $25.5 \pm 0.1^{\mathrm{a}}$ & $33.0 \pm 0.2^{\mathrm{b}}$ & $54.1 \pm 0.3^{\mathrm{d}}$ & $70.0 \pm 0.5^{\mathrm{e}}$ & $49.0 \pm 0.5^{\mathrm{c}}$ \\
$\mathrm{Fe}$ & $3.24 \pm 0.01^{\mathrm{b}}$ & $15.7 \pm 0.1^{\mathrm{f}}$ & $3.03 \pm 0.02^{\mathrm{a}}$ & $3.49 \pm 0.03^{\mathrm{c}}$ & $11.3 \pm 0.1^{\mathrm{e}}$ & $4.22 \pm 0.03^{\mathrm{d}}$ \\
$\mathrm{K}$ & $1040 \pm 23^{\mathrm{f}}$ & $28.2 \pm 0.5^{\mathrm{a}}$ & $200 \pm 5^{\mathrm{d}}$ & $371 \pm 8^{\mathrm{e}}$ & $139 \pm 3^{\mathrm{c}}$ & $90 \pm 2^{\mathrm{b}}$ \\
$\mathrm{Mg}$ & $160 \pm 3^{\mathrm{f}}$ & $57 \pm 1^{\mathrm{b}}$ & $73 \pm 3^{\mathrm{d}}$ & $87 \pm 3^{\mathrm{e}}$ & $65 \pm 2^{\mathrm{c}}$ & $20.5 \pm 0.2^{\mathrm{a}}$ \\
$\mathrm{Mn}$ & $0.72 \pm 0.01^{\mathrm{d}}$ & $2.30 \pm 0.04^{\mathrm{f}}$ & $0.25 \pm 0.01^{\mathrm{a}}$ & $0.54 \pm 0.01^{\mathrm{c}}$ & $0.35 \pm 0.01^{\mathrm{b}}$ & $1.41 \pm 0.04^{\mathrm{e}}$ \\
$\mathrm{Na}$ & $59 \pm 1^{\mathrm{b}}$ & $31.8 \pm 0.5^{\mathrm{a}}$ & $174 \pm 3^{\mathrm{f}}$ & $138 \pm 3^{\mathrm{d}}$ & $145 \pm 2^{\mathrm{e}}$ & $108 \pm 2^{\mathrm{c}}$ \\
$\mathrm{P}$ & $121 \pm 2^{\mathrm{f}}$ & $42 \pm 1^{\mathrm{a}}$ & $65 \pm 1^{\mathrm{c}}$ & $59.3 \pm 0.5^{\mathrm{b}}$ & $43.4 \pm 0.5^{\mathrm{a}}$ & $106 \pm 1^{\mathrm{e}}$ \\
$\mathrm{Sr}$ & $0.24 \pm 0.00^{\mathrm{e}}$ & $0.090 \pm 0.001^{\mathrm{a}}$ & $0.14 \pm 0.00^{\mathrm{b}}$ & $0.19 \pm 0.01^{\mathrm{c}}$ & $0.20 \pm 0.01^{\mathrm{c}}$ & $0.22 \pm 0.00^{\mathrm{d}}$ \\
$\mathrm{Zn}$ & $1.76 \pm 0.05^{\mathrm{f}}$ & $0.153 \pm 0.005^{\mathrm{a}}$ & $0.79 \pm 0.04^{\mathrm{c}}$ & $1.47 \pm 0.08^{\mathrm{e}}$ & $0.35 \pm 0.01^{\mathrm{b}}$ & $1.33 \pm 0.07^{\mathrm{d}}$ \\
\hline
\end{tabular}

Values represent the mean \pm SD of three replicates $(n=3)$. Different lowercase letters in same row indicate that values are significantly different $(p<0.05)$ under the limit of detection for the methodology used (with LOD of $39,43,3.8$ and $1.8 \mu \mathrm{g} / \mathrm{L}$, respectively). B1 was the honey with the highest concentration for K $(4895 \mathrm{mg} /$ $\mathrm{kg})$ showing significant differences $(p<0.05)$ with other honey samples, where the remaining honeys presented a range of concentrations between 656 and $708 \mathrm{mg} / \mathrm{kg}$ respectively, similar to the range reported for Malaysian honeys $904.9-617.6(\mathrm{mg} / \mathrm{kg})$ [36].

For honey samples $\mathrm{D} 1$ and $\mathrm{E} 1$, the $\mathrm{K}$ content was similar: $690.00 \pm 15.00$ and $708 \pm 15$, respectively, and no significant differences were observed, which is expected due to these honey samples come from the same region (Falcon State), where the predominant agroclimatic conditions correspond to an arid climate with xerophytic vegetation. The behavior was different when the comparison for $\mathrm{K}$ content was made between $\mathrm{A} 1$ and $\mathrm{B} 1$. Although both honeys come from the Miranda state, a significant difference was observed. In this case, the collection areas presented differences in their agroclimatic conditions and therefore, other parameters, considering that there are several parameters that influence the mineral content of honeys, such as temperature, humidity, soil and floral type, among others [29]. Differences were also observed for content of $\mathrm{P}, \mathrm{Mg}$, and Fe for honeys samples $\mathrm{A} 1$ and $\mathrm{B} 1$ from Miranda state, but for the remaining elements were not relevant. Results for Aragua state were similar for K content in comparison with results from Miranda state with no significant differences observed. Aragua and Miranda state are neighboring states and share similarities in their agro-climatic conditions. Due to their diversity in relief and altitudes that these states have in all their extension, there are different thermal floors in which the temperature tends 
to have different climatic characteristics with high humidity and a warm climate, giving rise to the existence of a diversity of available vegetation.

Levels of $\mathrm{K}, \mathrm{Mg}$ and $\mathrm{P}$ in Lara state showed no significant differences in comparison to results for these elements from Falcon State. In a similar stage for Miranda and Aragua, Falcon and Lara are neighboring states and share also similarities in their agroclimatic conditions. Microelements such as $\mathrm{Fe}$ and $\mathrm{Zn}$ were found in proportions ranged: $0.63-3.96$ and $0.69-0.84 \mathrm{mg} / \mathrm{kg}$, respectively among states. Similar results were reported in Turkish honeys for Fe [37] and for Zn in honey originated from the vicinity of industrial town Košice (eastern Slovakia) [38]. While, works from Karabagias et al. 2019 and Louppis et al. [6, 19], also showed similar values both $\mathrm{Fe}$ and $\mathrm{Zn}$ in honeys from Greece, Cyprus, Egypt, Spain, and Morocco. In a local context, artisanal honeys were also compared with the work of Sulbarán De Ferrer et al. [28]who studied Venezuelan honeys from Zulia State with average concentration (mg/ kg) for $\mathrm{Na}$ (353), K (1774), Ca (237), Mg (52), Cu (0.76), Fe (13.5), $\mathrm{Mn}(0.92)$ and $\mathrm{P}(1642)$, where the differences found were probably due to the botanical species, characteristics and agro-climatic conditions of Zulia state, located in the north-western part of Venezuela. According to Karabagias et al. [19], the variability in mineral content among honeys from different botanical species may consider a basic tool for honey variety differentiation, where the use of chemometrics as specific mineral markers, may be describe.

Regarding results for commercial honeys, significant differences $(p<0.05)$ for all minerals studied were found among samples from different geographical regions, probably due to different and not standardize procedures used in the processing of commercial honeys. $\mathrm{K}$ was the most abundant element in commercial honeys from Portuguesa (A2 with $1040 \mathrm{mg} / \mathrm{kg}$ ) and Miranda state (C2, and D2, with 200 and $371 \mathrm{mg} / \mathrm{kg}$, respectively). After potassium, sodium was the next most abundant element in honeys E2 and F2 from Carabobo y Cojedes state, while in B2, another commercial honey from Miranda state presented $\mathrm{P}$ as the most abundant mineral. B2, C2 and D2 with similar origins presented significant differences in concentration among minerals studied. In general, the range of elements studied in commercial honeys were (mg/kg): B 0.44-4.95, Ba 0.27-0.58, Ca 25.5-71.9, Fe 3.03-15.7, K 28.2-1040, Mg 20.5-2.30, Mn 0.25-2.30, Na 31.8-174, P 42-121, Sr $0.09-0.24$ and $Z n$ 0.35-1.76. On the other hand, an extensive qualitative study in all commercial honeys was carried out for $\mathrm{Pb}, \mathrm{As}, \mathrm{Hg}, \mathrm{Cd}$ but were not detected.

By comparison, the mineral content between artisanal and commercial honey from the same state was made, a not clear tendency was observed, reflecting that the mineral content is influenced by many environmental parameters, even by the preservation and processing strategies used for the treatment of commercial honeys. Additionally, the study in all commercial honeys was carried out for $\mathrm{Pb}$, As, $\mathrm{Hg}, \mathrm{Cd}$ but were not detected. The presence of metals in honey has been linked with the existence of hives close to contamination sources, such as factories, highways, volcanoes, or mines/mine tailings, even pollution sources can also comprise agrochemicals that contain cadmium and arsenic, among others [12, 39].

The average recovery percentages in all elements ranged from $90-115 \%$ and were found within accepted levels (80-115\%), according to AOAC International [40]. As no certified reference material is commercially available for trace elements in honey, the accuracy for the selected analytical strategy for pretreatment of samples was evaluated by a spike recovery analysis at two (2) known concentrations (5 and $10 \mathrm{mg}^{-\mathrm{L}^{-1}}$ ) of $\mathrm{B}, \mathrm{Ba}, \mathrm{Ca}, \mathrm{Fe}, \mathrm{K}, \mathrm{Mg}, \mathrm{Mn}, \mathrm{Na}$, Sr, and $\mathrm{Zn}$. In this context, Table 4 shows results for this evaluation, where percentages of recovery ranged between 85 and $107 \%$ approximately, which were considered acceptable because they were close to the established range as valid for this type of test (95-105\%) [41].

\section{Conclusions}

A new mineral analysis of artisanal and commercial honeys from Venezuela was successfully developed. The acid digestion strategy was selected for the analysis of all honey samples, which proved to be effective and reliable for a simultaneous and direct multi-elemental determination as routine analysis of honeys using ICP-OES. It showed good precision, accuracy and the quantification and detection limits were acceptable for each element. $\mathrm{K}, \mathrm{P}$ and $\mathrm{Na}$ were the major elements found in artisanal and commercial honeys, with significant differences for all

Table 4 Accuracy of the analytical method used to mineral analysis in honey samples and limits of detection and quantification

\begin{tabular}{lcrlll}
\hline Element & \multicolumn{2}{l}{ Recovery (\%) } & & \multicolumn{2}{l}{ Limit $(\mathrm{mg} / \mathrm{L})$} \\
\cline { 2 - 3 } \cline { 6 - 6 } & $5 \mathrm{mg} / \mathrm{L}$ & $10 \mathrm{mg} / \mathrm{L}$ & & LOD & LOQ \\
\hline $\mathrm{B}$ & $114 \pm 6$ & $107 \pm 10$ & & 0.008 & 0.026 \\
$\mathrm{Ba}$ & $113 \pm 7$ & $102 \pm 3$ & & 0.011 & 0.038 \\
$\mathrm{Ca}$ & $106 \pm 1$ & $92 \pm 1$ & & 0.034 & 0.113 \\
$\mathrm{Fe}$ & $92 \pm 2$ & $90 \pm 3$ & & 0.007 & 0.026 \\
$\mathrm{~K}$ & $112 \pm 4$ & $102 \pm 1$ & & 0.322 & 1.073 \\
$\mathrm{Mg}$ & $94 \pm 1$ & $97 \pm 1$ & & 0.005 & 0.018 \\
$\mathrm{Mn}$ & $94 \pm 2$ & $92 \pm 1$ & & 0.004 & 0.013 \\
$\mathrm{Na}$ & $115 \pm 7$ & $110 \pm 1$ & & 0.022 & 0.075 \\
$\mathrm{P}$ & $99 \pm 2$ & $97 \pm 5$ & & 0.189 & 0.632 \\
$\mathrm{Sr}$ & $101 \pm 6$ & $98 \pm 1$ & & 0.001 & 0.003 \\
$\mathrm{Zn}$ & $96 \pm 3$ & $99 \pm 4$ & 0.005 & 0.017 \\
\hline
\end{tabular}


elements among the samples from different locations. The concentration differences in Venezuelan honey samples were huge and this could be attributed to the geographical distribution of Venezuela that implies differences in climatic conditions.

Regarding regulations and quality control guidelines for Venezuelan honeys, requirements are focused on moisture, diastase activity, HMF, ash, $\mathrm{pH}$, acidity and nitrogen content, but for minerals, there is a lack in currently available regulations and guidelines. A higher number of honey samples from all the different locations and, higher control of the relevant conditions to consider in studies of chemical compositions of honeys is necessary, however, the results reported in this work can represent a good input due to the restricted information regard to the mineral profile of Venezuelan honeys, considering the special characteristics as a tropical country, suitable for apiculture and with a great potential for growth the marketing of this product. This preliminary work has encouraged us to develop more extensive work to continue studying the mineral profile of Venezuelan honeys.

Acknowledgements This work was supported by the Venezuelan Institute for Scientific Research (IVIC). We would like to thank as well the invaluable help of Mrs. Solsire Hulge. Mr. Melanio Sulbarán. and Mr. Yorbin González for honey samples collection.

\section{Compliance with ethical standards}

Conflict of interest The author(s) declared no conflict of interest with respect to the authorship and/or publication of this article.

\section{References}

1. Codex Alimentarius Commission: Revised Codex Standard for Honey. Codex Stand 12-1981, Rev. 1, 2001

2. Đogo Mračević S, Krstić M, Lolić A, Ražić S (2020) Comparative study of the chemical composition and biological potential of honey from different regions of Serbia. Microchem J 152:104420

3. Sajid M et al (2020) Comparative study of physio-chemical analysis of fresh and branded honeys from Pakistan. Saudi J Biol Sci 27(1):173-176

4. Bilandžić $\mathrm{N}$ et al (2019) Element content in ten Croatian honey types from different geographical regions during three seasons. J Food Compos Anal 84:103305

5. White JW (1975) Composition of honey. In: Crane E (ed) Honey: a comprehensive survey. Heinemann, London, pp 157-206

6. Louppis AP, Karabagias IK, Papastephanou C (2019) Two-way characterization of beekeepers ' honey according to botanical origin on the basis of mineral content analysis using ICPOES implemented with multiple chemometric tools. Foods 8(10):1-13

7. Lachman J, Kolihová D, Miholová D, Kosata J, Titera D, Kult K (2007) Food chemistry analysis of minority honey components: possible use for the evaluation of honey quality. Food Chem 101:973-979

8. Bogdanov S (2014) The book of honey. Bee Product Science, Valencia, España
9. Sixto A, Mollo A, Knochen M (2019) Fast and simple method using DLLME and FAAS for the determination of trace cadmium in honey. J Food Compos Anal 82:103229

10. Pohl P (2009) Determination of metal content in honey by atomic absorption and emission spectrometries. Trends Anal Chem 28(1):117-128

11. Akbari B, Gharanfoli F, Khayyat MH, Khashyarmanesh Z, Rezaee $\mathrm{R}$, Karimi $\mathrm{G}$ (2012) Determination of heavy metals in different honey brands from Iranian markets. Food Addit Contam Part B Surveill 5(2):105-111

12. Mejías E, Garrido T (2017) Analytical procedures for determining heavy metal contents in honey: a bioindicator of environmental pollution. In: Honey analysis, Chapter 14. IntechOpen, Croatia

13. Conti ME, Canepari S, Finoia MG, Mele G, Astolfi ML (2018) Characterization of Italian multifloral honeys on the basis of their mineral content and some typical quality parameters. $J$ Food Compos Anal 74(August):102-113

14. Á. Hernández González, Principios de bioquímica clínica y patología molecular. Elsevier España, 2010.

15. M. Hernández Rodríguez and A. Sastre Gallego, Tratado de Nutrición. Madrid, 1999.

16. Mohammed F, Abdulwali N, Guillaume D, Bchitou R (2018) Element content of yemeni honeys as a long-time marker to ascertain honey botanical origin and quality. LWT - Food Sci Technol 88:43-46

17. Ioannidou MD, Zachariadis GA, Anthemidis AN, Stratis JA (2005) Direct determination of toxic trace metals in honey and sugars using inductively coupled plasma atomic emission spectrometry. Talanta 65:92-97

18. Fredes $C$, Montenegro $G$ (2006) Heavy metals and other trace elements contents in chilean honey 1. Cienc e Investig Agrar 33:50-58

19. Karabagias IK, Louppis AP, Badeka A, Papastephanou C, Kontominas MG (2019) Nutritional aspects and botanical origin recognition of mediterranean honeys based on the " mineral imprint " with the application of supervised and non - supervised statistical techniques. Eur Food Res Technol 245(9):1939-1949

20. Tuzen M, Silici S, Mendil D, Soylak M (2007) Food chemistry trace element levels in honeys from different regions of Turkey. Food Chem 103:325-330

21. Vit P, Hernández Pérez J, Mercado R (2006) “REVISIÓN SOBRE EL CONOCIMIENTO DE LAS MIELES UNIFLORALES VENEZOLANAS", MedULA. Rev Fac Med Univ Los Andes 15:29-39

22. Principal J et al (2013) Physicochemical and sensory characterization of Apis mellifera L.'s honeys from Lara and Yaracuy States in Venezuela. Zootec Trop 31(2):119-128

23. Principal J et al (2012) Origen botánico de las mieles de Apis Mellifera L. producidas en la cuenca del Embalse Guaremal, Estado Yaracuy, Venezuela. Zootec Trop 30(1):91-98

24. Araujo D, Pérez-Cacho $P$, Serrano $S$, Dios-Palomares R, GalánSoldevilla H (2020) Sensory profile and physico-chemical properties of artisanal honey from Zulia, Venezuela. Foods 9(339):1-11

25. Ojeda De Rodríguez G, Sulbarán De Ferrer B, Ferrer A, Rodríguez $B$ (2004) Characterization of honey produced in Venezuela. Food Chem 84(4):499-502

26. Piccirillo GA, Rogríguez B, Ojeda de Rodríguez G (1998) Study of some physicochemical parameters of dry season honeys from eight bee zones of Zulia State, Venezuela. Rev la Fac Agron LUZ 15:486-497

27. Vit $P$ et al (2009) Expanded parameters to assess the quality of honey from Venezuelan bees (Apis melllifera). J ApiProduct ApiMedical Sci 1(3):72-81 
28. Sulbarán De Ferrer B, Ojeda De Rodríguez G, Peña J, Martínez J, Morán M (2004) Mineral content of the honey produced in Zulia state, Venezuela. Arch Latinoam Nutr 54(3):2-7

29. Mendes T, Baccan N, Cadore S (2006) Sample treatment procedures for the determination of mineral constituents in honey by inductively coupled plasma optical emission spectrometry. J Braz Chem Soc 17(1):168-176

30. Farooque $M$, Ahmed $F$ (2019) Minerals content in different types of local and branded honey. Heliyon 5(7):e02042

31. COVENIN, "Miel de Abeja. Requisitos 2191-84.," Caracas, Venezuela, 1984.

32. ICH, ICH HARMONISED TRIPARTITE GUIDELINE VALIDATION OF ANALYTICAL PROCEDURES: TEXT AND METHODOLOGY Q2(R1), Current Step 4 version. 2005.

33. Tuzen M, Soylak M, Elci L (2005) Multi-element pre-concentration of heavy metal ions by solid phase extraction on chromosorb 108. Anal Chim Acta 548:101-108

34. Suarez R, Arévalo E, Linares L, Ustáriz F, Hernández G (2009) Validación de un método analítico para la determinación de magnesio eritrocitario. Av en Química 4(2):53-62

35. Allen LB, Siitonen PH, Thompson HC (1997) Methods for the determination of arsenic, cadmium, copper, lead, and tin in sucrose, corn syrups, and high-fructose corn syrups by inductively coupled plasma atomic emission spectrometry. J Agric Food Chem 45(1):162-165

36. Kek SP, Chin NL, Tan SW, Yusof YA (2016) Classification of honey from Its bee origin via chemical profiles and mineral content. Food Anal Methods 10(1):19-30
37. Kılıç Altun S, Dinç H, Paksoy N, Temamoğulları FK, Savrunlu M (2017) Analyses of mineral content and heavy metal of honey samples from south and east region of Turkey by using ICP-MS. Int J Anal Chem 2017:1-6

38. Kováčik J, Grúz J, Biba O, Hedbavny J (2016) Content of metals and metabolites in honey originated from the vicinity of industrial town Košice (eastern Slovakia). Environ Sci Pollut Res 23(5):4531-4540

39. Ru Q, Feng Q, He J, Carlo M (2013) Risk assessment of heavy metals in honey consumed in Zhejiang province, southeastern China. Food Chem Toxicol 53:256-262

40. AOAC International (2002) AOAC Guidelines for Single Laboratory Validation of Chemical Methods for Dietary Supplements and Botanicals. Associationof Official Analytical Chemists, Arlington

41. Miller JN, Miller JC (2010) Statistics and chemometrics for analytical chemistry, 6 th edn. Pearson education, Canada

Publisher's Note Springer Nature remains neutral with regard to jurisdictional claims in published maps and institutional affiliations. 